Tropical Journal of Pharmaceutical Research March 2017; 16 (3): 501-507

ISSN: $1596-5996$ (print); 1596-9827 (electronic)

(c) Pharmacotherapy Group, Faculty of Pharmacy, University of Benin, Benin City, 300001 Nigeria.

All rights reserved.

Available online at http://www.tjpr.org

Original Research Article

http://dx.doi.org/10.4314/tjpr.v16i3.2

\title{
Antiproliferative effects of isoprenoids from Sarcophyton glaucum on breast cancer MCF-7 cells
}

\author{
Mohamed A Ghandourah ${ }^{1}$, Walied M Alarif ${ }^{1 \star}$, Ahmed Abdel-Lateff ${ }^{2,3}$, Khalid 0 \\ Al-Footy ${ }^{4}$, Mohamed Halid ${ }^{4}$, Sultan S Al-Lihaibi ${ }^{1}$ and Hajer S Alorfi ${ }^{4}$ \\ ${ }^{1}$ Department of Marine Chemistry, Faculty of Marine Sciences, King Abdulaziz University, Jeddah 21589, PO Box 80207, \\ ${ }^{2}$ Department of Natural Products and Alternative Medicine, Faculty of Pharmacy, King Abdulaziz University, Jeddah 21589, PO \\ Box 80260, Saudi Arabia, ${ }^{3}$ Department of Pharmacognosy, Faculty of Pharmacy, Minia University, Minia 61519, Egypt, \\ ${ }^{4}$ Department of Chemistry, Faculty of Science, King Abdulaziz University, PO Box 80203, Jeddah 21589, Saudi Arabia
}

${ }^{*}$ For correspondence: Email: wailed1737@yahoo.com

\begin{abstract}
Purpose: To evaluate the anticancer activity of isoprenoids of Sarcophyton glaucum on MCF-7 cells and to investigate the potential synergistic effect of doxorubicin.

Methods: Isolation and purification of isoprenoids were performed by applying different planar chromatographic methods (CC and PTLC). Further analyses of the isoprenoids by nuclear magnetic resonance (NMR) and mass spectrometry (MS) carried out to identify the compounds. Sulforhodamine$B$ (SRB) assay was used to determine the cytotoxic activity of the compounds against the MCF-7 human cell line. Flow cytometric analysis was used to assess their impact on cell cycle of MCF-7. Combination index $(\mathrm{Cl})$, when the compounds were combined with doxorubicin, was calculated to determine possible synergism. The isoprenoid compounds were also incubated at $1 / 4$ or $1 / 2$ of their respective half-maximal concentration $\left(I_{50}\right)$ with equimolar concentrations of doxorubicin.

Results: Four known isoprenoid derivatives (1-4) were identified as 10(14)-aromadendrene (1), sarcophinediol (2), ent-deoxysarcophine (3) and sarcotrocheliol acetate (4). It was observed that cells accumulated in pre-G phase as well. $\mathrm{Cl}$ of compound 3 with doxorubicin was 0.67 and 0.79 , respectively, at $1 / 4$ and $1 / 2$ of $I C_{50}$, indicating overt synergism. This was confirmed by re-assessing the cell cycle stages of MCF-7 cells.

Conclusion: The results indicate that compound 3 exhibits promising cytotoxicity as well as synergism with doxorubicin in MCF-7 cells. This is attributed, at least partly, to its ability to generate intercellular apoptosis induction.
\end{abstract}

Keywords: Sarcophyton glaucum, Combination index, Antiproliferation, Isoprenoidal derivatives, 10(14)-Aromadendrene, Sarcophinediol, Deoxysarcophine, Sarcotrocheliol acetate, Doxorubicin

Tropical Journal of Pharmaceutical Research is indexed by Science Citation Index (SciSearch), Scopus, International Pharmaceutical Abstract, Chemical Abstracts, Embase, Index Copernicus, EBSCO, African Index Medicus, JournalSeek, Journal Citation Reports/Science Edition, Directory of Open Access Journals (DOAJ), African Journal Online, Bioline International, Open-J-Gate and Pharmacy Abstracts

\section{INTRODUCTION}

The marine biota is characterized by ramification of the living organisms which live in the harsh perimeter [1]. Marine invertebrates, particularly soft corals, which lack of natural defenses (e.g., spines) lead to the production of defense metabolites [2].
Alcyonacea or soft corals constitute important organisms of marine invertebrates which are ubiquitous in the tropical sea waters. Moreover, they are considered as a prolific source of unique antiproliferative metabolites [3-5]. For instance, eleutherobin, a tricyclic diterpene displayed high potency in the in vitro induction of tubulin polymerization. This marine natural factor 
showed specific cytotoxicity toward several cell lines, including those of lung, ovarian, renal and lung [6]. The activity of eleutherobin in cancer cell therapy has been found to be comparable to that of taxol (a very active metabolite isolated from the terrestrial plant) [7].

Cancer is a dreadful disease and is the direct cause of almost $14.5 \%$ of all deaths across the world, which is found to increase with the aging of the population $[8,9]$. Amongst women, breast cancer is the most common type [10]. Anthracycline-based chemotherapy, particularly, doxorubicin (DOX) is used to treat early stage breast cancer [11]. However, it shows serious adverse effects, including cardiotoxicity [12]. Combining DOX with other cytotoxic agents has been suggested to enhance DOX cytotoxicity and avoid additional toxicity [8]. As combining factors with DOX, metabolites originated from natural sources (marine and terrestrial) and are strongly accepted from scientists and from the public communities, as well [13]. This recent paper further reported the cytotoxicity of isoprenoid derivatives (1-4) isolated from Sarcophyton glaucum (Figure 1) against MCF-7 and the potential synergistic effect of combining those compounds with DOX as well.

\section{EXPERIMENTAL}

\section{Equipment and reagents}

Chromatography: TLC plates (GF $245 \mathrm{Si}$ gel, Merck); PTLC plates (glass supported neutral $\mathrm{Al}_{2} \mathrm{O}_{3}, 20 \mathrm{~cm} \times 20 \mathrm{~cm}, 25 \mathrm{~mm}$, Merck) and CC (60 G Si gel, Merck). Solvents and Reagents: $\mathrm{CDCl}_{3}$, TMS, $50 \% \mathrm{H}_{2} \mathrm{SO}_{4} / \mathrm{CH}_{3} \mathrm{OH}$, were employed as a solvent for NMR measurements, an NMR internal standard, and a spray reagent, respectively. Doxorubicin, sulforhodamine-B (SRB) and dimethyl sulfoxide (DMSO) are Sigma-Aldrich products. Cell culture materials and fetal bovine serum are Lonza products. Instrument: NMR analysis (AVANCE III WM 600 $\mathrm{MHz}\left({ }^{1} \mathrm{H}\right)$ and $150 \mathrm{MHz}\left({ }^{13} \mathrm{C}\right)$, Bruker). TLC: Thin Layer Chromatography; PTLC: Prep. TLC; CC: Column Chromatography and TMS: Tetramethylsilane.

\section{Collection of S. glaucum}

In January 2014, at a depth of $5-10$ m of North Jeddah Red Sea coast in Saudi Arabia, $S$. glaucum belonging to Alcyonacea (order; family Alcyoniidae) was collected by SCUBA divers. A voucher specimen (no. SC-2014-10) was kept at Faculty of Pharmacy, KAU, Jeddah, KSA.

\section{Extraction and isolation}

In a mixture of dichloromethane miscible with methanol (2:1), $5 \mathrm{~kg}$ of $S$. glaucum was extracted for $24 \mathrm{~h}(10 \mathrm{~L} \times 3$ batches, room temp.). The extract was then filtered, evaporated and extracted under vacuum to obtain a black sticky residue. Re-extraction of the organic residue between water and diethyl ether using a separating funnel followed by drying of the ether layer resulted in getting $30 \mathrm{~g}$ ether fraction soluble extract.

The dried residue was physically partitioned on the Si gel column. The elution process was done using $n$-hexane, followed by a gradual increase in polarity with volumes of $\mathrm{Et}_{2} \mathrm{O}$ and then replaced volumes of EtOAc.

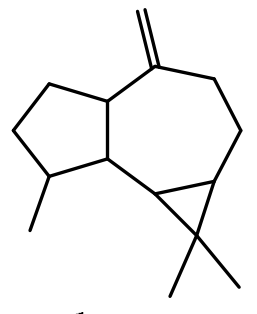

1

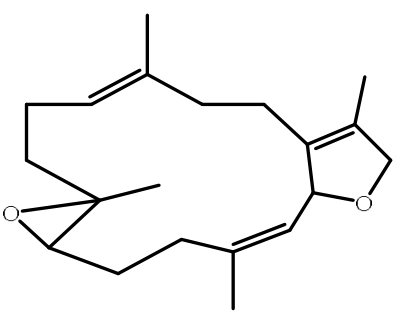

3
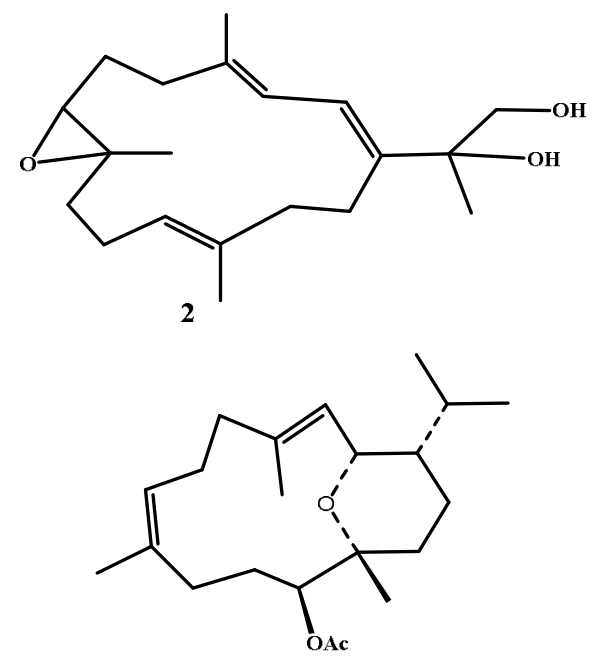

4

Figure 1: Terpenoids from Sarcophyton glaucum 
100 fractions were obtained (F 1-100), the homogeneity and the separation efficiency of the resulted fractions have been examined by investigating the TLC profile using $50 \%$ sulfuric acid reagent or the UV lamp. Purification of fraction F-3 $(300.0 \mathrm{mg})$ eluted with $5 \%$ diethyl ether in $n$-hexane using prep. TLC with the same elution system (Violet-red zone with $\mathrm{H}_{2} \mathrm{SO}_{4}$ reagent, $R_{f}=0.96$, colorless oil, $\left.22 \mathrm{mg}, 1\right)$. Purification of another one, F-13 (125.0 mg) eluted with $25 \%$ diethyl ether in $n$-hexane using prep. TLC with the same elution system afforded two distinguishable zones. The zone with $\mathrm{R}_{\mathrm{f}}=$ 0.71 (violet color with $\mathrm{H}_{2} \mathrm{SO}_{4}$ reagent, colorless oil, $16.0 \mathrm{mg}, 3)$. The mixture $n$-hexane:EtOAC (9:1) eluted fraction F-41 (123.0 mg), which was subjected to purification applying prep. TLC using the same solvent system with a different ratio (8:2) to give a band at $R_{f}=0.71$ (reddish color with $\mathrm{H}_{2} \mathrm{SO}_{4}$ reagent, colorless oil, $12.0 \mathrm{mg}$, 2). The last purified fraction, F-50 $(70.0 \mathrm{mg})$, i.e., that eluted with a mixture of $25 \%$ EtOAc in $n$ hexane, was purified by HPLC with RP-18 column and a composition of $\mathrm{MeOH} / \mathrm{H}_{2} \mathrm{O}(65: 35)$ to give metabolite $4(3.0 \mathrm{mg})$.

\section{Cytotoxicity assays and viability analysis}

Sulforhodamine assay was performed as formerly described by Tolba et al [14]. By using $0.25 \%$ Trypsin-EDTA, exponentially growing cells were collected and coated in 96-well plates at $1000-2000$ cells/well. The cells were laid bare for 48 hours to the compound under investigation, thereafter, in dark place incubation for 4 hours with SRB solution, which are then dissolved in DMSO. Measurement of color intensity was done at $750 \mathrm{~nm}$.

The equation \% Cell viability $=E_{\max } \times(1-M)+R$ is applied to estimate the dose response model of each metabolite, where $R$ is the resistance fraction (unaffected portion) and $M=[D]^{m} /\left[K_{d}\right]^{m}+$ $[D]^{m}$.

$\mathrm{K}_{\mathrm{d}}$ : compound concentration that causes a onehalf depress of the maximum inhibition rate, D: drug concentration used, and $E_{\max }=100-R$.

\section{Analysis of cell cycle distribution}

The pre-estimated $\mathrm{IC}_{50}$ test compound was treated with cells for 24 hours. The cells were then collected by trypsinization, washed with icecold phosphate buffer saline (PBS), and resuspended in PBS $(0.5 \mathrm{ml})$. Smoothly added ice-cold $\mathrm{EtOH}(10 \mathrm{ml}, 70 \%)$ with vortexing then left the cells at $4 \stackrel{\circ}{\circ} \mathrm{C}$ for $1 \mathrm{~h}$, the cells were kept at $-20 \stackrel{\circ}{\circ}$ till analysis. At the time of analysis, specific cells were washed and re-suspended in
$1 \mathrm{ml}$ of PBS containing $50 \mu \mathrm{g} / \mathrm{ml}$ RNase A and $10 \mu \mathrm{g} / \mathrm{ml}$ propidium iodide (PI). FACSVantageTM was applied to analyze the DNA cells contents, after 20 min incubation at $37^{\circ} \mathrm{C}$. 10,000 events were acquired for every sample. CELLQuest software was used to calculate the cell cycle distribution. Doxorubicin treated cells were employed as a positive control sample.

\section{Calculation of Combination Index}

Calculation of the Combination index (Cl-value) was formerly described by Chou et al [15]. The growing cells exposed to equitoxic concentrations of didox and DOX were subjected to SRB assay, and $E_{\max }$ model used to calculate $I_{50}$. The $C l=A / B+C / D$ equation determines the $\mathrm{Cl}$-value where $\mathrm{A}$ is the $I_{50}$ of compound $\mathrm{X}$ combination, $\mathrm{B}$ is the $I C_{50}$ of compound $\mathrm{X}$ alone, $\mathrm{C}$ is the $I C_{50}$ of drug compound combination and $\mathrm{D}$ are the $I_{50}$ of drug compound alone.

Where: at $\mathrm{Cl}=0.8$, the interaction of the drug works as synergism; when $\mathrm{Cl} \geq 1.2$, the interaction of the drug works as antagonism, while it is additive if $\mathrm{Cl}$ is between 0.8 and 1.2.

\section{Statistical analysis}

The results are expressed as mean \pm SEM. Graph Pad InStat software, version 3.05 was used for statistical analysis. The data were analyzed Student's t-test. $P<0.05$ was as statistically significant.

\section{RESULTS}

\section{Compounds}

Identification of the obtained isoprenoids was as follows:

10(14)-Aromadendrene(1): ${ }^{1} \mathrm{H}$ NMR (600 MHz): Chemical shift $\left(\delta_{\mathrm{H}}\right)=0.24(1 \mathrm{H}$, dd, $10.9,9.3 \mathrm{~Hz}$, $\mathrm{H}-6), 0.55$ (1H, ddd, 10.9, 9.3, $5.9 \mathrm{~Hz}, \mathrm{H}-7$ ), 0.94 $(3 \mathrm{H}, \mathrm{d}, 6.7 \mathrm{~Hz}, \mathrm{H}-4), 0.96(3 \mathrm{H}, \mathrm{s}, \mathrm{H}-12), 1.01(3 \mathrm{H}$, $\mathrm{s}, \mathrm{H}-13) .4 .74\left(1 \mathrm{H}, \mathrm{s}, \mathrm{H}_{\mathrm{a}}-14\right), 4.71\left(1 \mathrm{H}, \mathrm{s}, \mathrm{H}_{\mathrm{b}}-14\right)$; ${ }^{13} \mathrm{C}$ NMR $(150 \mathrm{MHz})\left(\delta_{\mathrm{C}}\right)=\mathrm{C}-1$ to $\mathrm{C}-15: 50.8$, $28.3,31.3,37.9,42.2,23.6,24.9,22.2,35.8$, $152.3,17.2,15.9,28.7,109.8$, and 16.4, respectively. The aforementioned data coincide with those reported in 10(14)-aromadendrene [16].

Sarcophinediol (2): ${ }^{1} \mathrm{H} \quad$ NMR $\quad(600 \mathrm{MHz})$ : Chemical shift $\left(\delta_{\mathrm{H}}\right)=6.43(1 \mathrm{H}, \mathrm{d}, 10.8 \mathrm{~Hz}, \mathrm{H}-1)$, $5.96(1 \mathrm{H}, \mathrm{dd}, 10.8,1.8 \mathrm{~Hz}, \mathrm{H}-3), 2.02(1 \mathrm{H}, \mathrm{m}, \mathrm{H}-$ 5), $1.30(1 \mathrm{H}, \mathrm{m} \mathrm{H}-5), 2.86(1 \mathrm{H}, \mathrm{dd}, 6.6,4.8 \mathrm{~Hz}, \mathrm{H}-$ 7), $5.12(1 \mathrm{H}, \mathrm{dd}, 6.6,12.6 \mathrm{~Hz}, \mathrm{H}-11), 1.92(2 \mathrm{H}, \mathrm{m}$, $\mathrm{H}-13), 3.66(1 \mathrm{H}, \mathrm{d}, 7.8 \mathrm{~Hz}, \mathrm{H}-16), 3.46(1 \mathrm{H}, \mathrm{d}$, 
$7.8 \mathrm{~Hz}, \mathrm{H}-16), 1.33(3 \mathrm{H}, \mathrm{s}, \mathrm{H}-17), 1.80(3 \mathrm{H}, \mathrm{s}, \mathrm{H}-$ 18), $1.25(3 \mathrm{H}, \mathrm{s}, \mathrm{H}-19), 1.60(3 \mathrm{H}, \mathrm{s}, \mathrm{H}-20) ;{ }^{13} \mathrm{C}$ NMR $(150 \mathrm{MHz})\left(\delta_{\mathrm{C}}\right)=\mathrm{C}-1$ to C-20: 144.0, 120.0, $121.0,138.0,38.5,23.2,62.3,60.0,25.9,26.3$, 125.3, 135.7, 35.6, 41.2, 76.2, 68.9, 16.1, 17.8, 24.3, and 17.0; respectively. The aforementioned data are coincide with those reported for Sarcophinediol [17].

Deoxosarcophine (3): ${ }^{1} \mathrm{H} \quad \mathrm{NMR} \quad(600 \mathrm{MHz})$ : Chemical shift $\left(\delta_{H}\right)=5.52(1 \mathrm{H}$, br d, $9.0 \mathrm{~Hz}, \mathrm{H}-2)$, $5.23(1 \mathrm{H}, \mathrm{d}, 9.0 \mathrm{~Hz}, \mathrm{H}-3), 2.34(2 \mathrm{H}, \mathrm{m}, \mathrm{H}-5), 2.7$ $(1 \mathrm{H}, \mathrm{t}, 7.2 \mathrm{~Hz}, \mathrm{H}-7), 2.105 .10(1 \mathrm{H}, \mathrm{dd}, \mathrm{J}=6.0$, $4.8 \mathrm{~Hz}, \mathrm{H}-11), 1.91$ (2H, m, H-13), $2.54(1 \mathrm{H}, \mathrm{m}$, $\mathrm{H}-14 \mathrm{a}), 1.66$ (1H, m, H-14b), 4.49 (2H, m, H-16), $1.65(3 \mathrm{H}, \mathrm{s}, \mathrm{H}-17), 1.61(3 \mathrm{H}, \mathrm{s}, \mathrm{H}-18), 1.27(3 \mathrm{H}$, s, H-19), $1.83\left(3 \mathrm{H}\right.$, br s, H-20); ${ }^{13} \mathrm{C}$ NMR (150 $\mathrm{MHz})\left(\delta_{\mathrm{C}}\right)=\mathrm{C}-1$ to $\mathrm{C}-20: 128.0,83.7,126.3$, $139.5,38.0,25.3,62.0,60.0,39.9,23.5,123.6$, $136.8,36.9,26.1,131.4,78.3,10.2,15.1,16.9$, and 15.6; respectively. The aforementioned data coincide with those reported for deoxosarcophine [17].

Sarcotrocheliol acetate (4): ${ }^{1} \mathrm{H}$ NMR $(600 \mathrm{MHz})$ : Chemical shift $\left(\delta_{\mathrm{H}}\right)=1.26(1 \mathrm{H}, \mathrm{m}, \mathrm{H}-1), 4.52(1 \mathrm{H}$, dd, 10.8, $5.4 \mathrm{~Hz}, \mathrm{H}-2), 5.50(1 \mathrm{H}, \mathrm{d}, \mathrm{J}=10.8 \mathrm{~Hz}$, $\mathrm{H}-3), 5.05(1 \mathrm{H}$, dd, 10.2, $4.8 \mathrm{~Hz}, \mathrm{H}-7), 5.37(1 \mathrm{H}$, $\mathrm{d}, \mathrm{J}=10.2 \mathrm{~Hz}, \mathrm{H}-11), 1.17(1 \mathrm{H}, \mathrm{m}, \mathrm{H}-15), 0.69$ (3H, d, 6.6 Hz, H-16), 0.82 (3H, d, $6.6 \mathrm{~Hz}, \mathrm{H}-17)$, $1.62(3 \mathrm{H}, \mathrm{s}, \mathrm{H}-18), 1.56(3 \mathrm{H}, \mathrm{s}, \mathrm{H}-19), 1.04(3 \mathrm{H}$, s, H-20), 2.06 (s, $\left.\underline{\mathrm{CH}}_{3} \mathrm{CO}\right) ;{ }^{13} \mathrm{C}$ NMR (150 MHz): $\delta_{\mathrm{C}}=171.0(\mathrm{C}=\mathrm{O}), 21.3\left(\mathrm{CH}_{3} \underline{\mathrm{CO}}\right), 46.5,71.4$, 125.3, 139.0, 39.8, 25.3, 124.5, 135.0, 34.4, 29.0
73.5, 73.7, 34.3, 19.0, 29.0, 20.3, 20.7, 15.0, 17.0, and 25.4; respectively. The aforementioned data coincide with those reported for sarcotrocheliol acetate [18].

\section{Cytotoxicity assays and viability analysis}

The antiproliferative activity of factors 1-4 were evaluated against the MCF-7 cell line and the results showed $\mathrm{IC}_{50}$ values of $18.70 \pm 1.10,8.80 \pm$ $0.90,13.9 \pm 1.00$ and $18.5 \pm 1.60 \mathrm{mg} / \mathrm{ml}$, respectively.

\section{Cell cycle distribution}

The study of the possible mode action of the antiproliferative effects of 1, 2, 3, and 4, thus, the cell cycle analysis was evaluated (Figures 2 and 3).All compounds decreased the population in $S$ phase from $31.99 \pm 2.90$ to $18.39 \pm 1.91,16.10 \pm$ $1.71,10.27 \pm 0.81$ and $22.63 \pm 1.81 \%$. Moreover, they induced a compensatory increase in the population in the fraction G0/G1 (non-proliferating cells) from $55.42 \pm 1.30$ to $73.46 \pm 2.81,68.63 \pm 1.80,59.17 \pm 1.31$ and $66.16 \pm 0.151 \%$. All compounds induced compensatory decreased the population of MCF7 in G2/M phase from $10.82 \pm 1.10$ to $7.02 \pm$ $0.61,13.50 \pm 1.81,5.28 \pm 0.60$ and $6.66 \pm 1.30$ $\%$, respectively. Finally, compound 3 , increased the accumulation of MCF-7 population in the pre$\mathrm{G}$ phase by $23.28 \pm 1.61 \%$ which indicates its apoptotic effect.

Table 1: Cytotoxicity of the combination, and combination Index of compounds 1-4 against MCF-7 ${ }^{a}$

\begin{tabular}{|c|c|c|c|c|c|}
\hline \multirow[b]{2}{*}{ Compound } & \multicolumn{5}{|c|}{$\mathrm{IC}_{50}(\boldsymbol{\mu M})$} \\
\hline & $I C_{50}$ & $\begin{array}{c}\text { Combination } \\
I C_{50} b\end{array}$ & $C r^{c}$ & $\begin{array}{c}\text { Combination } \\
I_{I C_{50}}\end{array}$ & $\mathrm{Cl}$ \\
\hline 1 & $18.70 \pm 1.10$ & $8.70 \pm 0.81^{e}$ & 08.16 & $5.00 \pm 0.60$ & 04.69 \\
\hline 2 & $08.80 \pm 0.90$ & $13.50 \pm 0.90$ & 13.48 & $9.70 \pm 0.92$ & 09.69 \\
\hline 3 & $13.90 \pm 1.00$ & $0.70 \pm 0.07$ & 00.67 & $0.81 \pm 0.09$ & 00.79 \\
\hline 4 & $18.50 \pm 1.60$ & $11.00 \pm 1.04$ & 09.78 & $12.90 \pm 1.50$ & 12.11 \\
\hline Doxorubicin & $1.13 \pm 0.08$ & - & & - & \\
\hline
\end{tabular}

${ }^{2}$ MCF-7 (human breast Cancer cell line); ${ }^{b} \mathrm{IC}_{50}$ of the combination of $1 / 4 \mathrm{IC}_{50}$ of doxorubicin and $1 / 4 \mathrm{IC}_{50}$ of the compounds; "Combination Index was calculated according to Chou and Talalay equation; ${ }^{d} \mathrm{IC}_{50}$ of the combination of $1 / 2 \quad \mathrm{IC}_{50}$ of Doxorubicin and $1 / 2 \quad \mathrm{IC}_{50}$ of the compounds; ${ }^{e}$ data are presented as Mean \pm standard error of the mean $(n=3)$

Table 2: FACSCAN results of the marine samples in MCF-7

\begin{tabular}{lcccc}
\hline Sample & \multicolumn{4}{c}{ Cell cycle phase (\%) } \\
\cline { 2 - 5 } & Pre-G & Go/G1 & S & G2/M \\
\hline Control & $1.77 \pm 0.20$ & $55.42 \pm 1.30$ & $31.99 \pm 2.90$ & $10.82 \pm 1.10$ \\
$\mathbf{1}$ & $1.13 \pm 0.091$ & $73.46 \pm 2.81$ & $18.39 \pm 1.91$ & $7.02 \pm 0.61$ \\
$\mathbf{2}$ & $1.75 \pm 0.035$ & $68.63 \pm 1.80$ & $16.10 \pm 1.71$ & $13.50 \pm 1.81$ \\
$\mathbf{3}$ & $23.28 \pm 1.61$ & $59.17 \pm 1.31$ & $10.27 \pm 0.81$ & $5.28 \pm 0.60$ \\
$\mathbf{4}$ & $1.55 \pm 0.051$ & $66.16 \pm 0.151$ & $22.63 \pm 1.81$ & $6.66 \pm 1.30$ \\
\hline
\end{tabular}

Data are presented as mean \pm SEM $(\mathrm{N}=3)$; * Significantly different from corresponding control value at $p<$ 0.05 


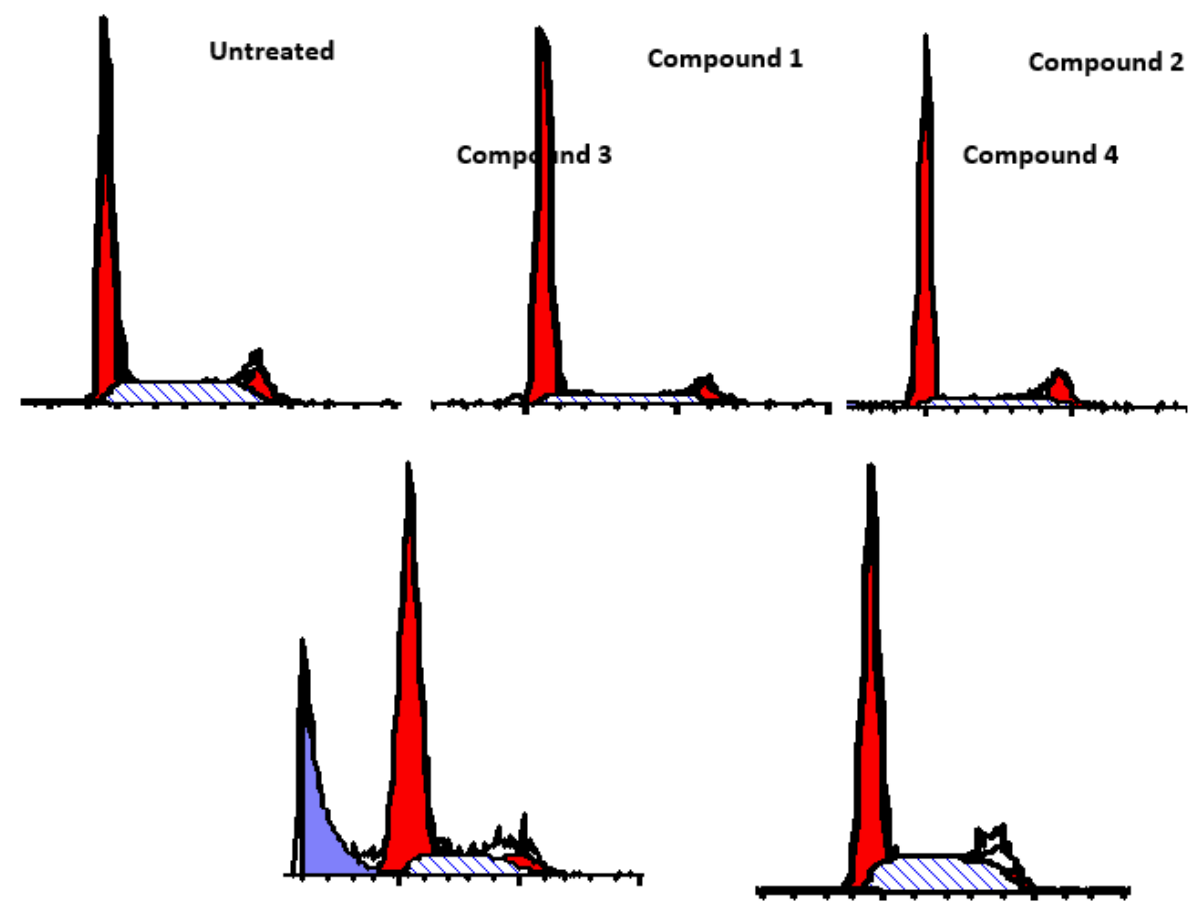

Figure 2: FACSCAN of the tested compounds MCF-7 cancer cells were exposed to compounds (1-4). DNA cytometry analysis was used to determine cell cycle distribution and different cell phases were plotted as percent of total events $(n=3)$
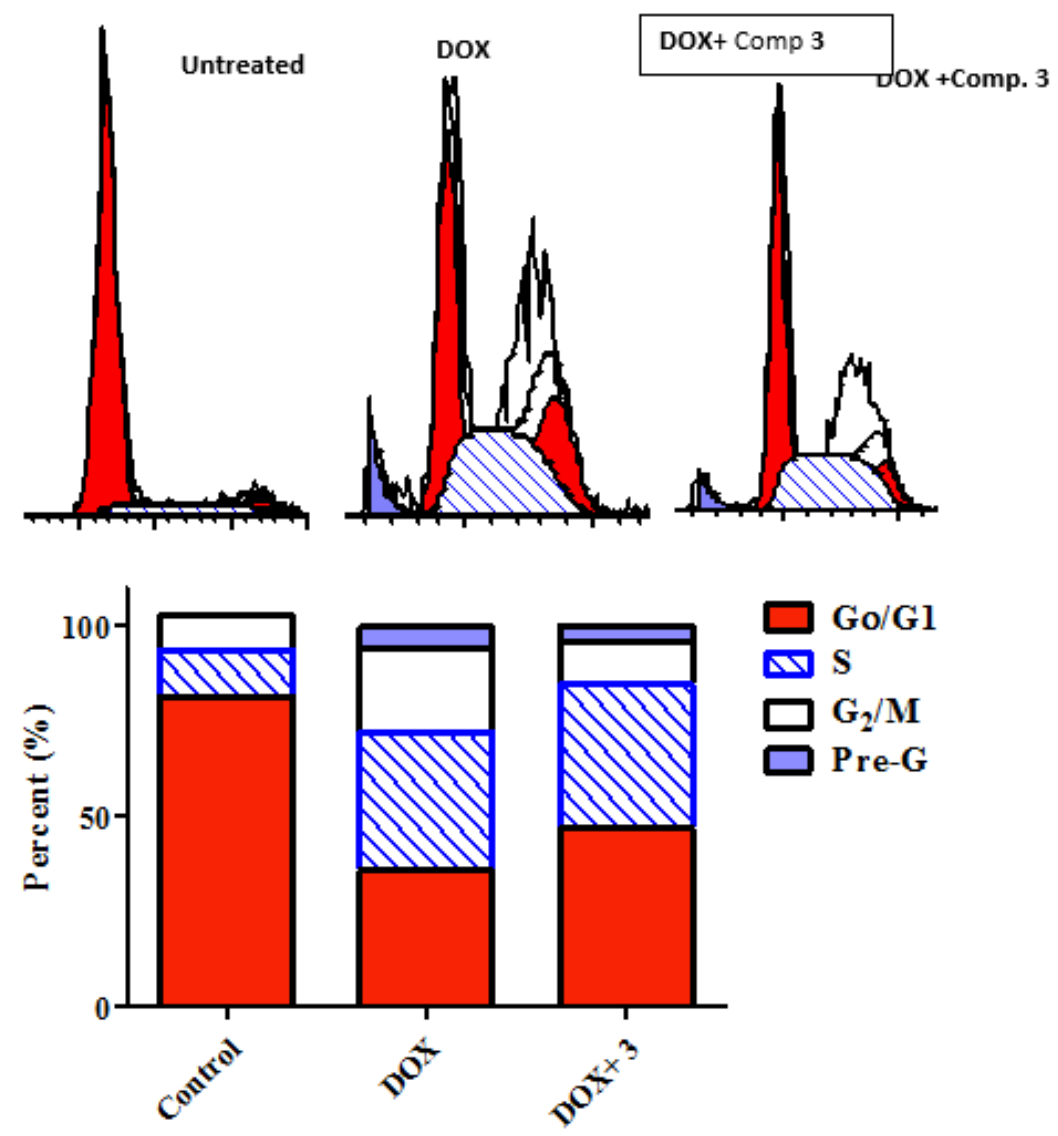

Figure 3: Effect of combination of DOX and $\mathbf{3}$ on the MCF-7 cell cycle distribution. Cells were assayed with doxorubicin and combination of doxorubicin. DNA cytometry analysis was used to determine cell cycle distribution and different cell phases were plotted as percent of total events $(n=$ $3)$. 


\section{DISCUSSION}

Compounds 1-4 exhibited cytotoxic activity against MCF-7 cells with $\mathrm{IC}_{50} \leq 20 \mu \mathrm{M}$. These compounds have been estimated by the flow cytometry assay aimed at evaluating their effects on the cell cycle of MCF-7 cells. The $\mathrm{Cl}$ (combination index) was evaluated to discover the possible synergistic potential, thus, decreasing the doxorubicin concentration and side effects.

The capability of inducting of intercellular apoptosis could be the main reason of the observed antiproliferative activity of the tested compounds. Thus, the combination index (Table 2) was used to calculate the synergistic potential. This was performed by incubating the reagents together with the equimolar concentration of $1 / 4$ and $1 / 2$ of the $I_{50}$ concentration of both doxorubicin and compounds 1-4. The $\mathrm{IC}_{50}$ values of all combinations had increases than those obtained from either DOX alone or the compounds 1-4alone, except for compound $\mathbf{3}$, that showed decreases in the IC50to be $0.70 \pm 0.07$ and $0.81 \pm 0.09 \mu \mathrm{M}$ (Table 1). While the IC50of the combinations, DOX and compounds 1, 2, and 4 have been increased. Compounds 1, 2, and 4 showed synergistic activity when combined with the doxorubicin in the range 4.69 to 13.48 , which indicate the antagonistic effects. Compound $\mathbf{3}$ showed synergistic activity when combined with the doxorubicin with combination indices (IC) values, 0.67 and 0.79 which fully agree with the Chou and Talalay value for the synergisticeffect of $\leq$ 0.8 .

\section{CONCLUSION}

Chemical investigation of Red Sea marine animal $S$. glaucum, led to the isolation of four compounds belonging to the mevalontes (1-4). All compounds showed cytotoxic activity with $\mathrm{IC}_{50}$ in the range $8.80 \pm 0.90$ to $18.70 \pm 1.10 \mu \mathrm{M}$ against breast cancer cell lines (MCF-7). The antiproliferative activity of the test compounds can be ascribed to their ability to induce intercellular apoptosis. Compound $\mathbf{3}$ produced a synergistic effect with doxorubicin while the effects of compounds 1,2 and 4 were antagonistic.

\section{DECLARATIONS}

\section{Acknowledgement}

This project was funded by Deanship of Scientific Research (DSR), at King Abdulaziz University, Jeddah (grant no. G-226-980-37) and also kindly provided technical support.

\section{Conflict of Interest}

No conflict of interest associated with this work.

\section{Contribution of Authors}

The authors declare that this work was done by the authors named in this article and all liabilities pertaining to claims relating to the content of this article will be borne by them.

\section{Open Access}

This is an Open Access article that uses a funding model which does not charge readers or their institutions for access and distributed under the terms of the Creative Commons Attribution License (http://creativecommons.org/licenses/by 14.0) and the Budapest Open Access Initiative (http://www.budapestopenaccessinitiative.org/rea d), which permit unrestricted use, distribution, and reproduction in any medium, provided the original work is properly credited.

\section{REFERENCES}

1. Blunt JW, Copp BR, Munro MH, Northcote PT, Prinsep MR. Marine natural products. Nat Prod Rep 2011; 28: 196-268.

2. Grabowski K, Schneider G. Properties and architecture of drugs and natural products revisited. Curr Chem Biol 2007; 1: 115-127.

3. Weinheimer AJ, Spraggins RL.The occurrence of two new prostaglandin derivatives (15-epi-PGA2 and its acetate, methyl ester) in the gorgoniaPlexaurahomomalla, chemistry of coelenterates XV. Tetrahedron Lett 1969; 59: 5185-5188.

4. Aceret TL, Coll JC, Uchio Y, Sammarco PW. Antimicrobial activity of the diterpenes flexibilide and sinulariolide derived from SinulariaflexibilisQuoy and Gaimard 1833 (Coelenterata: Alcyonacea, Octocorallia). Com pBiochem Physiol Part C 1998; 120: 121-126.

5. Valmsen $K$, Jarving I, Boeglin WE, Varvas $K$, Koljak $R$, Pehk T, Brash AR. The origin of 15Rprostaglandins in the Caribbean coral Plexaurahomomalla: Molecular cloning and expression of a novel cyclooxygenase. Proc Natl Acad Sci USA 2001; 98: 7700-7705.

6. Faulkner DJ. Marine pharmacology.Antonie Van Leeuwenhoek 2000; 77: 135-145.

7. Altmann $\mathrm{KH}$, Gertsch J. Anticancer drugs from nature natural products as a unique source of new microtubulestabilizing agents. Nat Prod Rep 2007; 24: 327-357.

8. Avendan̆o C, Menéndez JC. Medicinal Chemistry of Anticancer Drugs 2nd Edition. Elsevier 2015

9. Al-Alwan M, Olabi S, Ghebeh H, Barhoush E, Tulbah A, Al-Tweigeri T. Fascin is a Key Regulator of Breast 
Cancer Invasion That Acts via the Modification of Metastasis-Associated Molecules. PLOS ONE 2011; 6(11): e27339.

10. El-Serag HB. Hepatocellular carcinoma. New England J Med 2011; 365: 1118-1127.

11. Weiss RB. The anthracyclines: will we ever find a better doxorubicin. Seminars in Oncology 1992; 19: 670-686.

12. Vejpongsa $P$, Yeh ET. Prevention of anthracyclineinduced cardiotoxicity: challenges and opportunities. J Am Coll Cardiol 2014; 64: 938-945.

13. Bauer BA. Herbal therapy: what a clinician needs to know to counsel patients effectively. Mayo Clin Proc. 2000; 75(8): 835-41.

14. Tolba FM, Esmat A, Al-Abd MA, Azab SS, Khalifa EAE, Mosli AH, Abdel-Rahman ZS, Abdel-Naim BA. Caffeic acid phenethyl ester synergistically enhances docetaxel and paclitaxel cytotoxicity in prostate cancer cells. IUBMB Life 2013; 65: 716-729.
15. Chou TC, Talalay P. Quantitative analysis of dose-effect relationships: The combined effects of multiple drugs or enzyme inhibitors. Adv Enzyme Regul 1984; 22: 27-55.

16. Abdel-Lateff A, Alarif WM, Ayyad SEN, Al-Lihaibi SS, Basaif SA. New cytotoxic isoprenoid derivatives from the Red Sea soft coral Sarcophyton glaucum. Nat Prod Res 2015; 29: 24-30.

17. Al-Footy KO, Alarif WM, Asiri F, Aly MM, Ayyad SEN. Rare pyrane-based cembranoids from the Red Sea soft coral Sarcophyton trocheliophorum as potential antimicrobial-antitumor agents. Med Chem Res 2015; 24: 505-512.

18. Al-Lihaibi SS, Alarif WM, Abdel-Lateff A, Ayyad SEN, Abdel-Naim BA, El-Senduny FF, Badria FA. Three new cembranoid-type diterpenes from Red Sea soft coral Sarcophyton glaucum: Isolation and antiproliferative activity against HepG2 cells. Eur J Med Chem 2014; 81: 314-322. 